\title{
Francois Mauriceau (1637-1709) and maternal posture for parturition
}

\author{
P M Dunn
}

Francois Mauriceau had an extensive practice in midwifery in Paris, both private and in the Hotel Dieu, which was at that time the leading establishment for lying in women in Europe. In 1668 , when only 31 , he published his great work Traité des Maladies des Femmes Grosses et Accouchées, ${ }^{1}$ which according to André Levret 'drew from the cradle' the art of midwifery. ${ }^{2}$ Two years later Mauriceau received a visit from Hugh Chamberlen, a member of the British family that possessed the secret of the obstetric forceps, who then translated his text making it available to the English speaking world. The influence of this work on many aspects of midwifery was immense, ${ }^{3}$ and Mauriceau is still remembered eponymously for his description of delivery of the after coming head in breech presentation. Mauriceau's book also contains a section entitled 'Of children newborn and their ordinary Distempers, together with necessary directions to chuse a Nurse'. Among the 18 chapters are ones on 'Of cutting the Tongue when Tongue-ty'd' and 'How to cure the Venereal Lues in Infants'. Perhaps, though, in retrospect his greatest impact was in the influence his advice had on the position that women should adopt during delivery. From earliest times women throughout the world had usually assumed an upright posture during parturition. In Europe the birthing chair was particularly popular. ${ }^{4}$ As Atwood has written ${ }^{5}$ : 'The first major obstetrical change in the position of the parturient occurred when Francois Mauriceau substituted the bed for the birth stool. The time honoured 'position' assumed in an obstetric chair was replaced with the recumbent position to facilitate examinations and obstetric operations for the obstetrician'.

Let us study what Mauriceau actually wrote on this subject:

'The bed must be so made, that the woman being ready to be delivered, should lie on her back upon it, having her body in a convenient figure, that is, her head and breast a little raised, so that she be neither lying or sitting; for in this manner she breathes best, and will have more strength to help her pains, than if she were otherwise, or sunk down in her bed. Being in this posture, she must spread her thighs abroad,

University of Bristol, Southmead Hospital Correspondence to: Professor P M Dunn Department of Child Health, Southmead Hospital, Southmead Road, Bristol BS10 5NB. folding her legs a little towards her buttocks . . . and have her feet stayed against some firm thing; besides this, let her hold some persons with her hands, that she may better stay herself during her pains ... bearing them

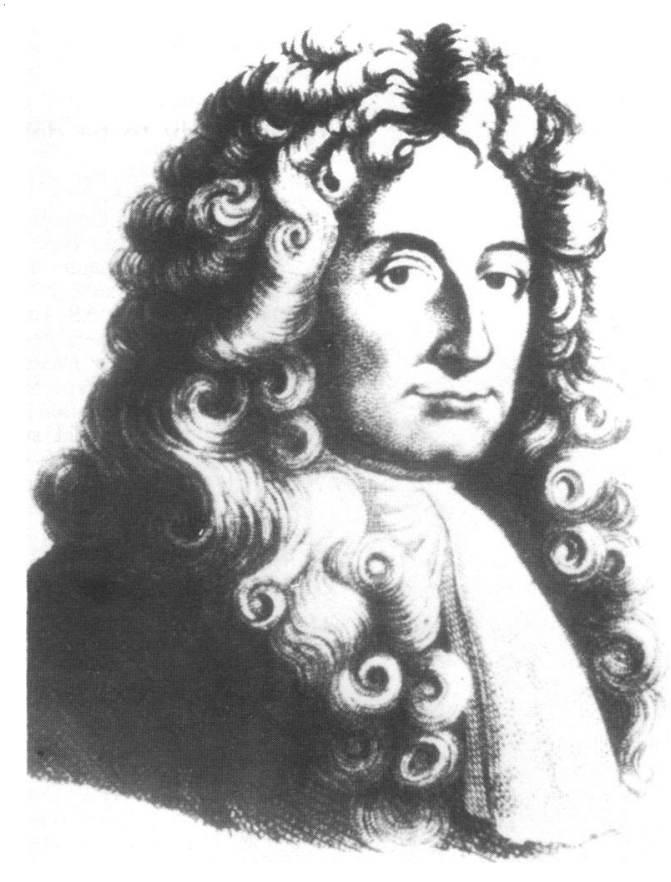

Francois Mauriceau of Paris, 1637-1709.

down when they take her, which she may do by holding her breath, and forcing herself, as much as she can, just as when she goeth to stool . . . .

The semirecumbent delivery position described by Mauriceau became known as the 'French' position and its use steadily spread throughout Europe and North America during the centuries that followed. Gradually in many countries it evolved into the fully recumbent or lithotomy position. More recently, with the diffusion of Western obstetrics, the dorsal position has also been introduced into many developing countries. Though some authors have credited Mauriceau with this change in delivery position, ${ }^{3}$ others regard the dorsal recumbent posture to be the most mischievous intervention in modern obstetrics, causing parturition to be more drawn out, more painful for the mother, and less safe for the fetus. ${ }^{6}$ To be fair to Mauriceau it should be recorded that he also recommended ambulation during labour, writing:

'. . . she may walk about her chamber . . . The patient may likewise by intervals rest herself on her bed, to regain her strength; but not too long, especially little, or short thick women, for 
they have always worse labours if they be much on their beds in their travail, and yet much worse of their first children, than when they are prevailed with to walk about the chamber, supporting them under their arms, if necessary; for by this means, the weight of the child, the woman being on her legs, causeth the inward orifice of the womb to dilate sooner than in bed; and her pains to be stronger and frequenter, that her labour be nothing near so long.'

Until recently I shared the belief that Mauriceau had introduced the dorsal recumbent position for delivery. Then, by chance, I came across the following passage in an 18th century English translation of Aristotle's Experienced Midwife, written around $350 \mathrm{BC}$ :

'The bed ought to be ordered, that the woman, being ready to be delivered, should lie on her back upon it, having her body in a convenient posture; that is her head and breast a little raised so that she be between lying and sitting; for being so placed, she is best capable of breathing, and likewise will have more strength to bear her pains, than if she lay otherwise, or sank down in her bed. Being so placed, she must spread her thighs abroad, folding her legs a little towards her buttocks . . . and let her feet be staid against some firm thing; besides this let her take hold of some of the good women attending her with her hands that she may the better stay herself during her pains . . . bearing them down when they take her, which she must do by holding in her breath, and forcing herself as much as possible, in like manner when she goes to stool . . .'

Nobody comparing this excerpt with the earlier one cited from Mauriceau can remain in doubt that the latter lifted his recommendation on delivery position straight from Aristotle. The evidence is even stronger when it is remembered that both English texts had already been translated from either their original Greek or French. It was unfortunate that Mauriceau plagiarised Aristotle in this instance: for Hippocrates, Soranus of Ephesus, ${ }^{7}$ and other classical authors all recommended an upright posture for parturition. Thus by strange chance, the disadvantageous dorsal position leapt two thousand years into post-renaissance Europe from its rare advocate in the distant past.

1 Mauriceau F. Traité des maladies des femmes grosses, et accouchées. Paris, 1668. (The disease of women with child, and in childbed. Translated by $\mathbf{H}$ Chamberlen, London, 1672.)

2 Cutter IS, Viets HR. A short history of midwifery. Philadelphia: WB Saunders Co, 1964:77-8.

3 Longo LD. Classic pages in obstetrics and gynecology: Francois Mauriceau. Am $\mathcal{F}$ Obstet Gynecol 1979;133:455-6.

4 Thompson CJS. The parturition chair: its history and use. Proceedings of the Royal Society of Medicine 1922;25:13-20.

5 Atwood RJ. Parturitional posture and related birth behaviour. Acta Obstet Gymecol Scand 1976;Suppl 57:1-25.
boof

behaviour. Acta Obstet Gynecol Scand 1976;Suppl 57:1-25.
6 Dunn PM. Maternal posture during labour and delivery: historical and anthropological aspects. In: Belfort P, Pinotti
inn torical and anthropological aspects. In: Belfort P, Pinotti Vol 4. Proceedings of the XIIth World Congress of Obstetrics and Gynecology, Rio de Janeiro, October 1988. Carnforth, Lancs: Parthenon Publications, 1989:173-7.

7 Soranus' gynecology. Translated by O Tempkin. Baltimore: Johns Hopkins Press, 1956. 